\title{
KEGIATAN RITUAL ZIARAH MAKAM HABIB HUSEIN ALAYDRUS DAN PENGARUHNYA TERHADAP PENGGUNAAN RUANG PUBLIK DI KAMPUNG LUAR BATANG
}

\author{
Ashadi $^{1}$, Anisa $^{2}$, Ratna Dewi Nur'aini ${ }^{3}$ \\ ${ }^{1,2,3}$ Program Studi Arsitektur Fakultas Teknik Universitas Muhammadiyah Jakarta \\ Cempaka Putih Tengah 27 Jakarta Pusat 10510 \\ ashadi@ftumj.ac.id, anisa@ftumj.ac.id, ratnadewina@ftumj.ac.id
}

\begin{abstract}
ABSTRAK. Kegiatan yang dilakukan oleh manusia akan mempengaruhi lingkungan sekitarnya. Penelitian ini membahas tentang kegiatan yang dilakukan pada Makam dan Masjid Bersejarah serta melihat pengaruhnya terhadap penggunaan ruang Publik. Objek studi yang diambil menjadi studi kasus adalah Makam dan masjid Luar Batang yang terletak di permukiman padat penduduk. Studi kasus ini diambil dengan pertimbangan bahwa Makam dan Masjid Luar Batang termasuk kawasan masjid bersejarah yang sampai saat ini masih ramai menjadi tujuan ziarah. Menariknya, Makam dan Masjid ini terletak di daerah padat penduduk yang minim ruang publik. Tujuan penelitian ini adalah untuk mendeskripsikan dan menginterpretasikan serta mendapatkan relasi dari kegiatan ritual ziarah Makam Habib Husein dengan penggunaan ruang publik di Kampung Luar Batang. Metode penelitian menggunakan deskriptif interpretatif terhadap data dan analisis secara kualitatif dengan sampel diambil secara purposif. Kegiatan yang diamati adalah kegiatan ritual ziarah Makam dan kegiatan yang dilakukan di ruang publik. Hasil yang didapatkan dari penelitian ini adalah ada relasi dari kegiatan ritual ziarah makam Habib Husein dengan penggunaan ruang publik di Sekitar Masjid Luar Batang. Kegiatan yang masuk dalam ritual ziarah makam antara lain berdo'a-sholat-mengaji di sekitar Makam, kegiatan akhir ziarah, haul habib Husein, dan pengajian di Masjid Luar Batang yang merupakan rangkaian dari ziarah. Sedangkan ruang publik pada Kampung Luar Batang yang berkaitan dengan kegiatan ziarah adalah halaman masjid Luar Batang dan jalanan umum. Kegiatan ritual ziarah makam menimbulkan kegiatan lain di ruang publik. Aktivitas lain yang dimaksud adalah aktivitas yang berhubungan dengan komersil dan kegiatan sosial.
\end{abstract}

Kata kunci : kegiatan ritual ziarah, makam Habib Husein, ruang publik, Kampung Luar Batang.

ABSTRACT. Activities undertaken by humans will affect the surrounding environment. This study discusses the activities conducted at the Tomb and the Historical Mosque as well as see the effect on the use of Public space. The object of the research taken into the case study is the Tombs and Masjid Luar Batang located in densely populated settlements. This case study was taken into the consideration that the Tombs and Masjid Luar Batang including the historic mosque which until now is still a busy pilgrimage destination. Interestingly, the Tomb and the Mosque is located in a densely populated area with minimal open space. The purpose of this research is to describe and interpret and get relation from the activity of pilgrimage Habib Hussein Habib with the use of public space in Kampung Luar Batang. The research method used descriptive interpretative of the data and analyzed qualitatively with the sample taken purposively. The activities observed were the activities of the pilgrimage rituals of the Tomb and the activities carried out in the public sphere. The results obtained from this research is no relation to the activities of pilgrimage Habib Husein tomb with the use of public space in the vicinity of Masjid Luar Batang. Activities included in the pilgrimage ritual of the tomb include praying around the Tomb, the end of the pilgrimage, haul Habib Hussein, and praying in Masjid Luar Batang which is a series of pilgrimages. While the public space in Kampung Luar Batang associated with the pilgrimage activities is the courtyard outside the Stem and public streets. The ritual pilgrimage activity of the tomb raises other activities in the public sphere, other activities in question are activities related to commercial and social activities.

Keywords: pilgrimage ritual activity, Habib Hussein's grave, public space, Kampung Luar Batang.

\section{PENDAHULUAN}

Kegiatan yang dilakukan oleh manusia membutuhkan sebuah wadah. Wadah itulah yang secara mikro disebut sebagai ruang.
Dalam arsitektur, ruang dipengaruhi oleh aktivitas yang dilakukan di dalamnya. Bentuk ruang, ukuran ruang dan setting ruang akan dipengaruhi aktivitas penggunanya. Dalam lingkup lebih luas, kegiatan bisa diwadahi oleh 
ruang-ruang dalam skala kawasan. Misalnya di lingkungan permukiman, kegiatan bersama bisa diwadahi dalam ruang bersama atau ruang publik. Pada permukiman padat perkotaan, peran ruang publik sangat besar. Hal ini disebabkan terbatasnya ruang yang dimiliki oleh pribadi. Studi kasus yang diambil dalam penelitian ini adalah Kampung Luar Batang, yang memiliki banyak keunikan. Kampung Luar Batang adalah sebuah kampung bersejarah karena adanya Makam Habib Husein dan Masjid Luar Batang yang ramai menjadi tujuan ziarah. Selain itu, Kampung Luar Batang terletak di permukiman padat perkotaan yang minim ruang publik.

Penelitian ini dimulai dengan mengamati fungsi dan bentuk ruang publik serta melihat keterkaitannya dengan kegiatan ritual ziarah. Fungsi dan bentuk merupakan unsur-unsur penting dalam arsitektur. Dalam periode arsitektur modern, yang dinamakan fungsi adalah aktivitas yang dilakukan oleh manusia di dalam suatu ruang tiga dimensional $[1,2]$. Wadah yang berupa ruang tiga dimensional yang menampung kegiatan tersebut dinamakan bentuk. [3]

Relasi yang ingin diketahui adalah relasi antara kegiatan ritual ziarah makam dengan penggunaan ruang publik di Kampung Padat perkotaan. Premis penelitian ini adalah kegiatan ritual ziarah Makam Habib Husein memiliki pengaruh terhadap penggunaan ruang publik di sekitarnya. Keterpengaruhan ini didasarkan pada faktor terbatasnya ruang publik yang ada di kampong tersebut.

Makam dan Masjid Luar Batang terletak di Kampung Luar Batang, Kelurahan Penjaringan, Kecamatan Penjaringan, Kodya Jakarta Utara. Berdasarkan wawancara didapatkan informasi bahwa Makam dan Masjid ini merupakan salah satu tempat bersejarah yang kelahirannya berbarengan dengan lahirnya kota Batavia atau Jakarta. Keunikan lain dari Makam dan Masjid Luar Batang dibandingkan dengan masjid-masjid bersejarah lainnya, yaitu, karena lokasinya dekat dengan pelabuhan Sunda Kelapa, dan adanya Makam Habib Husein yang menjadi tujuan ziarah. Pelabuhan sunda kelapa merupakan pelabuhan penting pada masa lalu. Sedangkan Makam Habib Husein dipandang sebagai sebuah makam keramat.

Kampung Luar Batang merupakan kampung kota yang memiliki nilai sejarah dan merupakan bagian dari kota tua Jakarta. Kampung Luar Batang dilindungi oleh undang- undang untuk dijaga kelestariannya dan mendapatkan hak konservasi. [4,5]

Kampung Luar Batang memiliki luas sekitar $131.500 \mathrm{~m}^{2}$ dan bersebelahan dengan kawasan Pasar Ikan (lama; sekarang dikenal dengan kampung Akuarium) yang memiliki luas sekitar $34.505 \mathrm{~m}^{2}$. Secara administratif Luar Batang terdiri dari $36 \mathrm{RT}$ dan 3 RW. [6].

Berdasarkan latar belakang tersebut maka penelitian ini bertujuan untuk : (1) mengidentifikasi dan mengetahui kegiatan berkaitan dengan ziarah makam Habib Husein bin Abubakar Alaydrus; (2) mengindentifikasi dan mengetahui ruang publik yang digunakan berkaitan dengan kegiatan ziarah; dan (3) mengidentifikasi dan mengetahui pengaruh kegiatan ritual ziarah terhadap penggunaan ruang publik di Kampung Luar Batang.

\section{METODE PENELITIAN}

Penelitian tentang ritual ziarah makam dan pengaruhnya terhadap penggunaan ruang publik ini menggunakan metode deskriptif interpretatif yang mengambil data dan menganalisisnya secara kualitatif. Ada beberapa langkah yang dilakukan dalam proses pengambilan data. Pertama, observasi kegiatan ritual ziarah Makam habib Husein. Kedua, observasi penggunaan ruang publik di Kampung Luar Batang. Observasi dilengkapi dengan kegiatan wawancara untuk mendapatkan informasi mengenai hal-hal yang sifatnya non fisik dan untuk mendapatkan keterangan penjelas dari kegiatan ritual ziarah dan penggunaan ruang publik.

Ada beberapa langkah yang dilakukan dalam upaya mencapai tujuan penelitian, yaitu : (1) merekam dan mendeskripsikan seluruh kegiatan ritual ziarah makam Habib Husein; (2) merekam dan mendeskripsikan bentuk ruang publik dan penggunaannya; (3) mengaitkan atau merelasikan kegiatan ritual ziarah dengan penggunaan ruang publik di Kampung Luar Batang; dan (4) menginterpretasi relasi tersebut untuk menarik kesimpulan. 


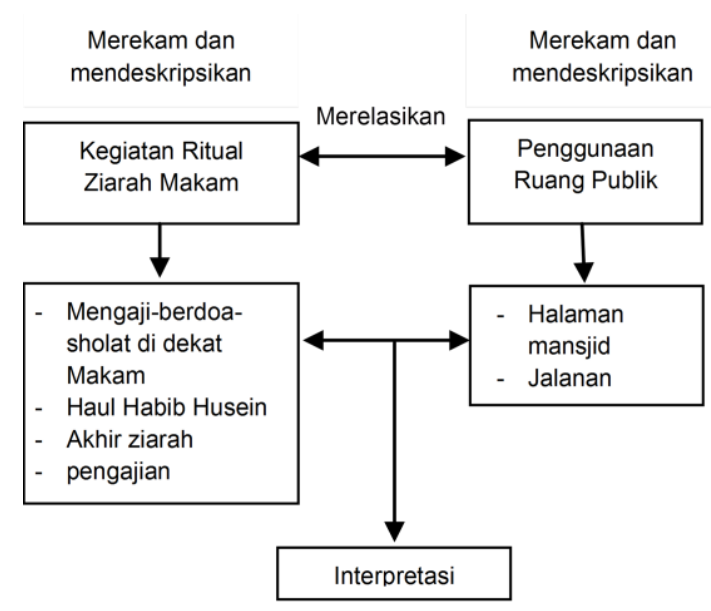

Gambar 1. Kerangka Penelitian

\section{HASIL DAN PEMBAHASAN}

\section{Makam dan Masjid Luar Batang}

Makam Habib Husein dan masjid Luar Batang terletak di Kampung Luar Batang, tepatnya di Kelurahan Penjaringan, Kecamatan Penjaringan, Kodya Jakarta Utara. Keberadaan masjid Luar Batang dan makam Habib Husein menyebabkan Kampung Luar Batang menjadi terkenal serta menjadi tujuan peziarah dan wisatawan.

Lokasi kampung Luar Batang, di sebelah timur dan selatan dibatasi oleh terusan Laut Jawa, di utara oleh pergudangan, dan di barat oleh jalan raya Gedong Panjang dan jalan Muara Baru. Berdasarkan observasi lapangan dan wawancara didapatkan data Kampung Luar Batang, yaitu terdiri dari 3 RW dan 36 RT. RW 01 memiliki 11 RT dan $700 \mathrm{KK}, \mathrm{RW} 02$ memiliki 12 RT dan 870 KK, RW 03 memiliki 14 RT dan 1000 KK. Masjid Luar Batang ada di RW 03.[3].

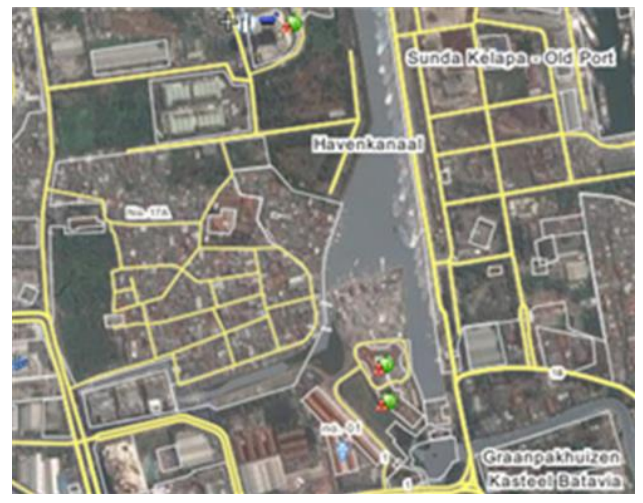

Gambar 2. Peta wilayah Kampung Luar Batang, Jakarta Utara (garis tebal hitam)

(Sumber : Wikimapia, 2017)
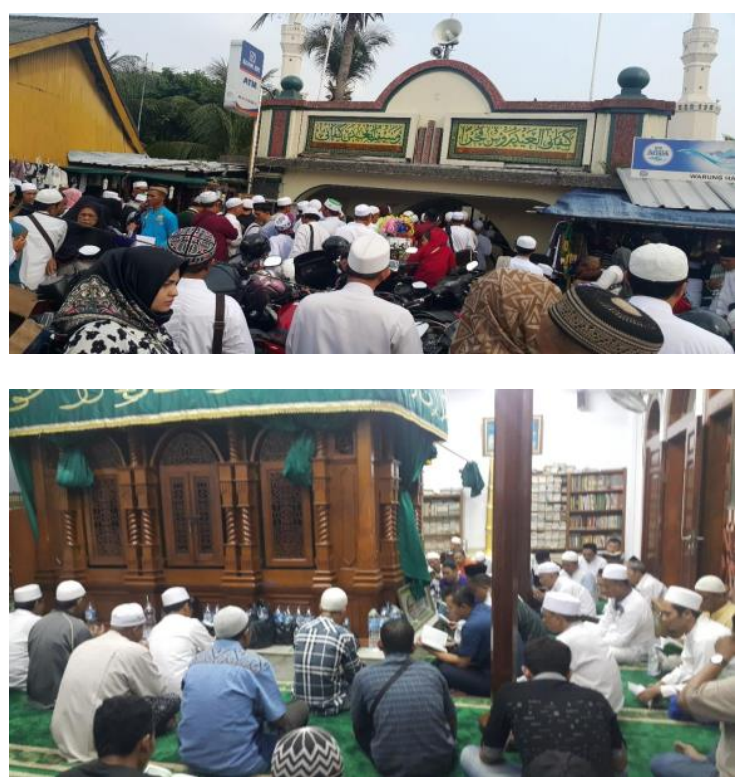

Gambar 3. Masjid Luar Batang dan Makam Habib Husein (Sumber : Ashadi, 2017) [7]

Masjid Luar Batang termasuk masjid terkenal di Batavia karena keramat Sayid Husein bin Abu Bakar bin Abdillah Alaydrus (wafat 1756). Masjid keramat ini menarik banyak peziarah. Masjid ini terletak di sebelah utara tembok kota lama, di daerah yang sesudah pertengahan abad ke-17 diuruk dan baru boleh dihuni oleh orang Jawa dari Cirebon sejak 1730. Mereka bertugas membersihkan mulut kali Ciliwung dari lumpur, supaya kapal bisa sampai ke Pasar Ikan yang letaknya tidak jauh dari mesjid ini. [8]

\section{Perekaman dan Pendeskripsian Kegiatan Ritual Ziarah Makam Habib Husein}

Perekaman dan pendeskripsian kegiatan ritual ziarah makam Habib Husein meliputi kegiatan harian, mingguan, dan tahunan. Kegiatan ritual ziarah harian meliputi : (1) Mengaji atau membaca Al-Qur'an di sekitar Makam Habib Husein; (2) Membaca doa atau berdzikir di sekitar Makam Habib Husein; dan (3) Sholat di dekat Makam Habib Husein.

Berada di samping Makam Habib Husein Bin Abubakar Alaydrus, dapat dilihat ada sebuah makam. Menurut wawancara dengan informan didapatkan informasi bahwa makam tersebut adalah makam Haji Abdul Qodir, seorang Tionghoa Muslim yang turut menyebarkan agama Islam di Luar Batang. Walaupun terletak berdekatan dengan makam Habib Husein namun makam Haji Abdul Qodir ternyata tidak menjadi tujuan ziarah. Kegiatan 
ziarah harian setiap harinya melibatkan jumlah peziarah sekitar $100-500$ orang.

Kegiatan ziarah harian dilakukan di ruangan samping masjid Luar Batang, yaitu ruang yang berisi makam Habib Husein dan makam haji Abdul Qodir. Tempat sekitar makam tersebut dibuat cukup luas dan dapat digunakan untuk sholat, berdoa dan membaca AIQur'an. Tempat untuk peziarah laki-laki dan perempuan dipisahkan pada ruangan tersebut.

Kegiatan mingguan yang berkaitan dengan ziarah adalah kegiatan pengajian. Pengajian dilakukan 3 kali dalam seminggu yaitu pengajian malam minggu, malam rabu dan malam jum'at. Pengajian diselenggarakan di dalam masjid, serambi dan pelataran. Pengajian yang paling banyak didatangi orang adalah pengajian malam jum'at. hal ini berkaitan erat dengan kegiatan ziarah yang mencapai puncaknya dalam seminggu pada malam Jum'at. Jumlah peziarah sekitar 1.0003.000 orang yang kebanyakan dari mereka sekaligus mengikuti pengajian malam Jum'at.

Hal ini memunculkan satu kegiatan baru yaitu kegiatan komersil berupa perdagangan bermacam-macam komoditas yang berpusat di pelataran dan halaman Masjid Luar Batang. Sejak ashar, para pedagang berdagangan dan mempersiapkan lapaknya. Selain di pelataran dan halaman masjid, para pedagang juga berjualan di jalanan sepanjang menuju Masjid Luar Batang.

Kegiatan tahunan berkaitan dengan ziarah Makam Habib Husein adalah haul Habib Husein dan akhir ziarah. Haul adalah memperingati wafatnya seorang ulama. Habib Husein lahir di Hadramaut, Yaman dan setelah dewasa beliau berdakwah sampai ke Batavia (tahun 1746) sampai wafatnya pada 24 Juni $1756 \mathrm{M}$ (17 ramadhan $1169 \mathrm{H})$.

Pada setiap acara haul yang jatuh pada minggu terakhir bulan Syawal masjid dan makam sudah ramai dari pagi. Saat shalat Dhuhur menjelang haul diikuti oleh sekitar $10.000-12.000$ orang. Sehingga tempat sholat tidak hanya di ruang utama saja tetapi juga sampai ke halaman masjid bagian depan, kanan, kiri dan teras ruang takmir masjid. Jumlah peserta acara Haul mencapai 25.000 orang sehingga bisa diceritakan Masjid dan makam akan penuh orang, sampai ke jalanjalan menuju ke Makam Habib Husein.

Meskipun wafat pada 17 Ramadhan namun acara haul diperingati setiap hari minggu di akhir bulan Syawal. Hal ini dilakukan karena ini merupakan ijtima 'dari para ulama dan habaib yang saat itu berada di bawah pimpinan Mufti Betawi yaitu Alhabib Utsman Bin Abdullah Bin Yahya. Di mana para penjajah saat itu masih menguasai dan transportasi yang sangat sulit sekali serta bertepatan dengan keadaan orang-orang yang sedang berpuasa, sehingga diputuskanlah oleh para ulama dan habaib agar pelaksanaan Haul Al-imam Husein Bin Abu Bakar Alaydrus diadakan pada akhir Minggu bulan Syawwal, di mana setelah orang-orang melakukan silaturrahim lebaranan barulah kembali berkumpul dan bersilaturrahim di pusara beliau untuk memperingati Haulnya Al-imam Husein Bin Abu Bakar Alaydrus. [9]

Kegiatan tahunan berkaitan dengan ritual ziarah yaitu haul dan akhir ziarah, dihadiri oleh jumlah jamaah berkisar 25.000-30.000. Dapat dibayangkan para peziarah tidak hanya memenuhi kompleks masjid saja tetapi sampai ke halaman, parkir, dan jalan menuju ke masjid Luar Batang. Kegiatan akhir ziarah diadakan pada tiga atau tujuh hari sebelum bulan Ramadhan. Peziarah yang hadir dalam kegiatan haul, dan akhir ziarah, akan berziarah juga ke makam Habib Husein.

\section{Perekaman dan Pendeskripsian Ruang Publik dan Penggunaannya pada Kampung Luar Batang}

Perekaman dan pendeskripsian ruang publik meliputi bentuk ruang publik dan pemanfaatan ruang publik tersebut. Berdasarkan observasi lapangan dan wawancara, di dapatkan bahwa ada beberapa ruang publik yang biasa digunakan oleh warga Kampung Luar batang yaitu halaman Masjid Luar Batang, Lapangan sekolah, jalanan, lapangan proyek, dan pesisir Sunda Kelapa.

Dari lima ruang publik tersebut, ada dua ruang publik yang berhubungan langsung dengan kegiatan ziarah makam Habib Husein yaitu halaman Masjid Luar Batang dan jalanan. Jalanan di Kampung Luar Batang merupakan jalanan yang berfungsi ganda artinya tidak hanya digunakan untuk jalur sirkulasi semata tetapi juga digunakan untuk kegiatan lain seperti kegiatan komersil dan kegiatan sosial.

Kondisi jalanan di Kampung Luar Batang beragam, mulai dari lebar 2 meter sampai lebar 5,5 meter. Kondisi fisik jalan juga beragam, ada yang sudah di beton rapih dan ditinggikan dari jalan semula. Namun ada juga yang masih campuran batu dan plesteran. 
Jalan yang paling lebar adalah jalan Luar Batang 2, lebarnya 5,5 meter, kondisi jalan beraspal. Jalan ini merupakan akses para pengunjung masjid Luar Batang dari arah jalan raya Gedong Panjang. Sedangkan yang paling sempit adalah jalan Jalan Luar Batang 8 dengan lebar 2 meter dan kondisi jalan berupa plesteran yang sebagiannya sudah aus.
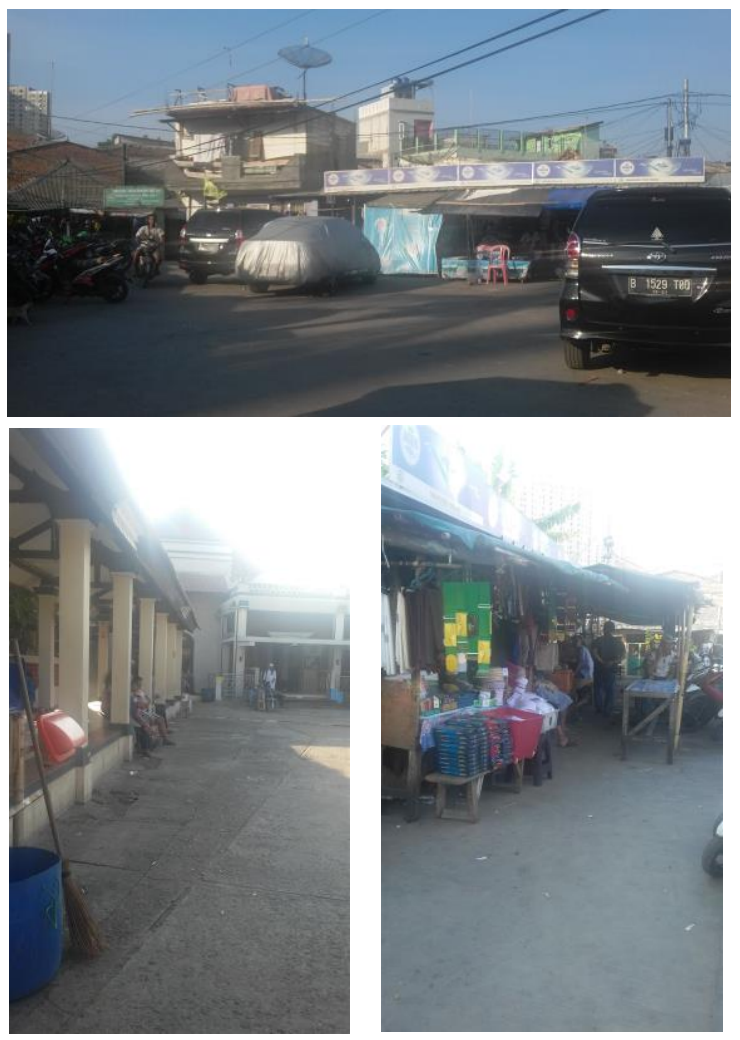

Gambar 4. Halaman Masjid dan jalanan (Sumber : Hasil Observasi, 2017)

Ruang publik halaman Masjid dan Makam digunakan untuk kegiatan komersil dan kegiatan sosialisasi. Kegiatan komersil ada yang permanen dengan membuka toko di sekitar halaman namun ada juga kegiatan komersil yang sifatnya insidentil seperti pasar malam Jum'at.

Bazaar atau pasar malam Jumat selain menempati halaman masjid, juga menempati jalanan yaitu ruas jalan Luar Batang 1 dan 5 , serta sebagian ruas jalan Luar Batang 7. Jalan yang digunakan untuk kegiatan komersil tidak ada kaitannya secara langsung dengan lebar jalan. Jalan yang digunakan untuk kegiatan komersil adalah Jalan yang berdekatan dan sering digunakan untuk akses menuju Masjid Luar Batang. Misalnya jalan luar Batang 2 yang letaknya relative jauh dari Masjid dan Makam walaupun cukup lebar tetapi tidak digunakan untuk berjualan bazaar.

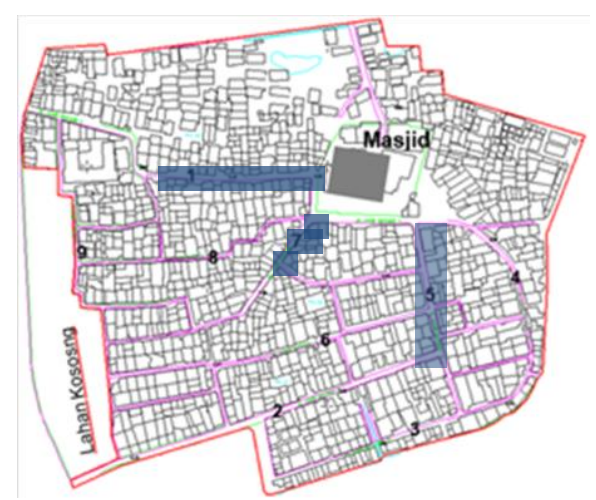

Gambar 5. Ruas Jalan Luar Batang 1,5,7, digunakan untuk bazaar

(Sumber : Hasil Observasi, 2017)

Hampir semua barang dagangan di jual di pasar malam Jumat. Warung makan dadakan, penjual minuman, aksesoris lengkap wanita dan pria, batu akik sampai makanan khas betawi, bugis dan makanan kekinian dapat dijumpai saat pasar malam jum'at.

Selain halaman masjid dan jalanan, sebagian rumah tinggal juga digunakan untuk usaha warung yaitu rumah-rumah yang berada di sisi-sisi jalan Luar Batang 1, 2, 5, dan sebagian jalan Luar Batang 7. Secara fisik arsitektural dapat dilihat fasade rumahnya berbeda dengan fasade rumah yang tidak digunakan untuk berjualan.

\section{Relasi dan Interpretasi}

Kegiatan ritual ziarah makam meliputi kegiatan ziarah harian, mingguan dan tahunan direlasikan dengan penggunaan ruang publik yang berkaitan dengan kegiatan tersebut di Kampung Luar Batang. Ruang publik secara umum di kampung Luar Batang ada 5 namun hanya 2 yang secara langsung berkaitan dengan kegiatan ziarah makam Habib Husein yaitu halaman masjid dan jalanan sekitar masjid.

Tabel 1. relasi antara Kegiatan ritual ziarah dengan penggunaan ruang publik

\begin{tabular}{|l|c|c|c|c|c|}
\hline $\begin{array}{l}\text { Kuang } \\
\text { Kegiatan }\end{array}$ & $\begin{array}{c}\text { Halaman } \\
\text { Masjid }\end{array}$ & jalan & $\begin{array}{c}\text { Lap } \\
\text { sekolah }\end{array}$ & $\begin{array}{c}\text { Lap } \\
\text { proyek }\end{array}$ & $\begin{array}{c}\text { Sunda } \\
\text { kelapa }\end{array}$ \\
\hline $\begin{array}{l}\text { Kegiatan } \\
\text { harian }\end{array}$ & Ada & Ada & tidak & tidak & tidak \\
\hline Pengajian & Ada & Ada & tidak & tidak & tidak \\
\hline Haul & Ada & Ada & tidak & tidak & tidak \\
\hline $\begin{array}{l}\text { Akhir } \\
\text { ziarah }\end{array}$ & Ada & Ada & tidak & tidak & tidak \\
\hline
\end{tabular}

(Sumber : Hasil Interpretasi, 2017) 
Keterpengaruhan kegiatan ritual ziarah makam Habib Husein terhadap penggunaan ruang publik di Kampung Luar Batang dibaca berdasarkan ada atau tidaknya relasi antara kegiatan ritual ziarah dengan penggunaan ruang publik.

Dari rekaman dan deskripsi yang sudah dibahas pada bagian sebelumnya, maka dapat dijelaskan relasi-relasi yang terjadi. Kegiatan ziarah harian memiliki relasi dengan penggunaan ruang publik yaitu halaman masjid dan jalanan. Meskipun relasi ini tidak kuat namun tetap ada relasi antar keduanya.

Kegiatan ziarah mingguan terutama saat pengajian malam Jum'at memiliki relasi yang cukup kuat dengan penggunaan ruang publik berupa halaman masjid dan jalanan di sekitarnya.

Kegiatan haul dan akhir ziarah memiliki relasi sangat kuat dengan penggunaan ruang publik karena saat kegiatan tersebut dilakukan, hanya sepertiga jamaah yang dapat ditampung di dalam masjid, selebihnya jamaah berada di halaman dan jalan menuju masjid.

Sedangkan untuk ruang publik yang lain yaitu lapangan sekolah, lapangan proyek, dan pesisir Sunda Kelapa tidak memiliki relasi dengan kegiatan ritual ziarah disebabkan lokasinya yang cukup jauh dari Masjid dan Makam.

Kegiatan yang masuk dalam ritual ziarah makam antara lain berdo'a-sholat-mengaji di sekitar Makam, kegiatan akhir ziarah, haul habib Husein, dan pengajian di Masjid Luar Batang yang merupakan rangkaian dari ziarah. Aktivitas ini bertempat di dalam masjid, pelataran dan halaman serta jalanan sekitar masjid. Misalnya kegiatan akhir ziarah, bisa diamati tidak hanya masjid dan pelataran saja yang penuh dengan peziarah, namun juga jalan-jalan yang menuju ke masjid.

Tingginya intensitas kegiatan ritual ziarah ke makam Habib Husein, menimbulkan terjadinya aktivitas lain di sekitar masjid. Aktivitas yang dimaksud adalah aktivitas yang bernilai komersial seperti adanya bazaar atau pasar malam Jum'at, munculnya warung-warung menjual minuman dan makanan, penjual perlengkapan ziarah, dan berbagai dagangan yang lain.

Ramainya masjid Luar Batang ini selain dimanfaatkan oleh pedagang dari berbagai daerah juga dimanfaatkan oleh masyarakat sekitarnya. Mereka bisa ikut berjualan di halaman masjid, di jalanan, di rumah ya atau sekedar meramaikan dengan banyak bersosialisasi di jalan-jalan sekitarnya.

\section{KESIMPULAN}

Ada beberapa kesimpulan yang didapatkan dari penelitian ini. Pertama, kegiatan ritual ziarah makam merupakan kegiatan penunjang yang sifatnya dominan dapat dilihat pada Masjid Luar Batang. Dapat dikatakan bahwa kegiatan ziarah makam inilah yang menjadi data tarik utama di Kampung Luar Batang.

Kedua, ada lima ruang publik yang digunakan oleh masyarakat di Kampung Luar Batang. Dari lima ruang publik tersebut, ada dua yang berkaitan dengan kegiatan ziarah yaitu halaman masjid Luar Batang dan jalanan menuju ke masjid Luar Batang.

Ketiga, ada relasi dan pengaruh yang ditimbulkan oleh kegiatan ritual ziarah makam Habib Husein bin Abubakar Alaydrus terhadap penggunaan ruang publik di Kampung Luar Batang.

Keterpengaruhan ini ditunjukkan oleh adanya relasi atau kaitan antara kegiatan ritual ziarah dengan pemanfaatan ruang publik. Kegiatan ritual ziarah yang berelasi meliputi kegiatan harian (berdoa-mengaji-sholat) di sekitar Makam, kegiatan mingguan (pengajian) dan kegiatan tahunan (haul dan akhir ziarah). Ruang publik yang berelasi meliputi halaman masjid (kadang digunakan untuk parkiran) dan jalanan sekitar Masjid (JI Luar Batang 1,5,7).

\section{UCAPAN TERIMA KASIH}

Tulisan ini merupakan bagian dari Penelitian Produk Terapan dengan judul Model Penataan Hunian di Sekitar Bangunan Bersejarah dalam Rangka Peningkatan Potensi Kawasan Wisata. Kasus Studi Hunian di Sekitar Masjid Luar Batang yang dilakukan dengan sumber dana yang dari Direktorat Riset dan Pengabdian Masyarakat, Direktorat Jendral Penguatan Riset dan Pengembangan Kementerian Riset, Teknologi dan Pendidikan Tinggi dengan Surat perjanjian Penugasan Pelaksanaan Hibah Penelitian Nomor 0404/K3/KM/2017 tanggal 24 Mei 2017. 


\section{DAFTAR PUSTAKA}

[1] Adorno, Theodor W. (1997). Functionalism Today. Rethinking Architecture: $A$ Reader in Cultural Theory. Leah, Neil (Ed.) London : Routledge.

[2] Heynen, Hilde. (1999). Architecture and Modernity. Massachusetts : MIT Press.

[3] Ashadi, Anisa, Ratna Dewi Nur'aini. (2017). Fungsi Masjid Bersejarah Luar Batang, Jakarta Utara, Dan Pengaruhnya Terhadap Pola Permukiman Di Sekitarnya. Jurnal Arsitektur Nalars Volume 16 No 2 Juli 2017. $p$-ISSN 1412-3266/e-ISSN 2549-6832. DOl10.24853/nalars.16.2.169178.

https://jurnal.umj.ac.id/index.php/nalars/arti cle/view/1358/1342

[4] Dinas Penataan dan Pengawasan Bangunan Propinsi DKI Jakarta. (2004). Buku Petunjuk Membangun di Propinsi DKI Jakarta.

[5] Iskandaria, Harfa, Ispurwono Sumarno, Johan Silas. (2013). Peran Kampung Luar Batang Kecamatan Penjaringan Jakarta Utara Dalam Menunjang Konservasi Kota Tua. Arsitron Vol 4 No 1 Juni 2013.

[6] Kasman,Tamiya Miftahu Saada. (2016). Hubungan Karakteristik Penduduk dengan Pemilihan Ruang Publik di Kampung Luar Batang, Jakarta Utara. Prosiding Temu IImiah IPLBI 2016.

[7] Ashadi, Anisa, Ratna Dewi Nur'aini. (2017). Function, Form, And Meaning Of Ritual And Market In Historical Site Of Kampung Luar Batang, Jakarta, Indonesia. International Journal of Research Granthaalayah Vol 5 Issue 10 Oktober 2017.

Issn- 2350-0530(O), Issn- 2394-3629(P).

Doi: 10.5281/Zenodo.1043202

http://granthaalayah.com/Publication-

Volume-5-Issue-10-October-Edition.html

[8] Heuken SJ., Adolf. (2003). Mesjid-mesjid tua di Jakarta. Jakarta : Yayasan Cipta Loka Caraka

[9] Anonim. 2017. Manaqib Habib Husein Bin Abu Bakar Alaydrus (Luar Batang). https://kicaunews.com/2017/03/25/manaqi b-habib-husein-bin-abu-bakar-alaydrusluar-batang/ 
